may be quickly and easily eliminated. Simulation may be studied rapidly without the introduction of other prisms of questionable strength.

\title{
REFERENCES
}

1. Maddox, E. E.-The Rod Test in Ocular Pareses and Paralyses. Ophthal. $R e v .$, p. 287, 1890.

2. Dolman, P.-Maddox Multiple Red Rod, Consideration of Some of Its Optical Defects. Arch. of Ophthal., Vol. XLIX, p. 194, 1920.

3. Schild, E. H.-Determination of Heterophoria. Ophthal. Rec., June, 1905.

4. Wray, C.-Cyclophorometer. Trans. Ophthal. Soc. U.K., Vol. XXXII, p. 163, 1912.

5. Ballantyne, A. J.-The Simultaneous Correction of Horizontal and Vertical Deviation, Facilitated by a Slight Modification of the Maddox Rod, Ophthal. Rev., Vol. XXXIII, p, 165, 1914.

6. Yates Mrs. (Mary Maddox).-Personal Communication, May 31, 1935.

\section{PHOSPHOLIPID CONTENT OF CATARACTOUS HUMAN LENSES*}

\author{
BY \\ P. W. Salit, M.D. \\ IOWA CITY
}

Litrle quantitative work has been done on the phospholipid content of crystalline lenses, especially those which are cataractous. Several reports of qualitative nature, however, have been published on myelin-like or birefractive substances in cataractous lenses. + Mettenheimer (185i) was the first to describe birefractive substances, regarded as myelin, in cataractous lenses; these were not found in normal lenses. Laptschinsky (1876) made the first quantitative estimation of lecithin in normal ox lenses and found it to constitute 0.23 per cent. of the dry weight, however the ages of the animals and method of analysis were not published. Cahn (1881) carried out a quantitative estimation of lecithin in both normal and cataractous human lenses; the former contained 0.63 and the latter 0.80-4.52 per cent. of the dry weight. But he, like his predecessors, neglected the age factor. Furthermore, no differentiation between lenses extracted by the intra- and extra-capsular methods was made. By the first method one obtains the entire lens, and by the second only the nucleus and a small amount of cortex. In later investigations all lipids, for which the lenses have been analyzed, were found to increase in both normal and cataractous lenses with advancing age; they have been found

\footnotetext{
- From the Department of Ophthalmology, State University of Iowa, U.S.A.

+ For a detailed discussion of myelins and birefractive substances found in cataractous lenses see Krause (1932, 1934, 1935).
} 
also in larger amounts in the nucleus as compared with the cortex (see bibliography by Salit and O'Brien, 1935). Cahn also gave no description of his method, but did state that the lenses were collected and preserved in alcohol until a sufficient number were obtained for an analysis. This feature in itself invalidates the results to a certain extent, since phospholipids in the tissue are now known to undergo various chemical changes on standing, even when preserved in alcohol (see Leinfelder and Salit, 1934). The importance of Cahn's work lies in the demonstration of lecithin in cataractous as well as in normal human lenses. Most of the later investigations have been qualitative in nature, simply corroborating earlier observations and adding only a few new discoveries. Thus Mlle. Toufesco (1906), as well as Vogt (1922), corroborated the findings of Mettenheimer as to the presence of myelin-like substances in cataractous lenses, and their absence in normal lenses; however, they also observed vacuole formations in connection with myelin. Mlle. Toufesco attributed these abnormalities to fatty degeneration. Myelins, such as those described by Mettenheimer, were also identified by Hoffman (1913) in more than thirty cataractous human lenses by means of a polariscope, whereas the results of his tests on normal lenses were doubtful. In 1914 he noted that myelins were present in lamellar, traumatic, complicated; and senile cataracts, also in the normal lens of the calf after autolysis or incubation in a weak alkaline solution for halfan-hour in the presence of thymol; he never found them in the normal human lens. He believed that myelin forms occurred after degeneration of the lens, chiefly through the action of certain enzymes resident in the lens tissue. Jess (1913) found no difference in the lecithin content of normal and cataractous ox lenses. Wessely (1922) reported having detected birefractive calcium soaps, phosphates, and carbonates mixed with cholesterol in cataractous lenses. According to Goldschmidt's (1922) quantitative tests on post-mortem human lenses, the phospholipid content of infant lenses up to one year of age is 0.41 per cent. of the dry weight. Between one and ten years it amounts to 3.13 per cent.; reaching its maximum between the ages of ten and twenty years. After the age of twenty the values vary between 4.13 and 4.43 per cent., the latter value being for ages between seventy and seventy-five years. Busacca (1925) found oil droplets in one case of black cataract; these evidently were of the same nature as those which Vogt (1922) and others found in senile cataracts which Vogt called myelin droplets. Kranz (1927), who studied both normal and cataractous human lenses with a polariscope, found myelin-like substances in seventeen out of twenty-five cataractous lenses. They were present also in cataracta brunescens. The myelins in ordinary light showed structures resembling droplets 
or sausage-like formations with pointed or round processes; they were transparent, somewhat yellowish in colour, and bicontoured; frequently they also appeared in the form of threads. He, contrary to Hoffmann's observation, noted that myelin was not birefractive in the lens after autolysis. Liquid spherocrystals were found only in senile lenses. Kranz analyzed ten traumatic cataracts produced by perforation, and the same number of lamellar cataracts, but found no birefractive myelins or spherocrystals. In four cases of traumatic cataract, produced by blunt injury, unusually large amounts of birefractive myelins as well as spherocrystals were present. Clear lenses never contained myelin or other birefractive lipids. Metzger (1931), also using a polariscope, examined seventy-five post-mortem human lenses among which were eleven with coronary cataract. The latter showed birefractive lipids and vacuoles between the lens fibres; in clear lenses they were absent. According to data from our laboratory, published in 1931, the average values of the phospholipid content of both normal animal lenses and cataractous human lenses are, in terms of wet weight, as follows : 0.119 per cent. for five week-old calves, 0.110 per cent. for two year-old oxen, 0.131 per cent. for rabbits, and 0.99 per cent. for twenty cataractous human lenses, with a variation between 0.48 and 1.88 per cent. The analyses were carried out by the colorimetric method of Whitehorn (1924). At that time, however, no attempt was made to classify the cataractous lenses into incipient, intumescent, and mature stages; neither was any distinction made between lenses extracted by the intra- and extra-capsular methods. For these reasons the data on cataractous lenses cannot be used in a comparative study. Krause (1935), who recently analyzed the lenses of one year old oxen, reports their phospholipid content to be 0.193 per cent. of the wet weight, or 0.575 . per cent. of the dry weight.

On the basis of the foregoing data the general opinion has been that cataractous lenses contain more phospholipids, especially lecithin, than do normal lenses. The present work, however, which was carried out on one hundred cataractous human lenses, extracted by the intra-capsular method, strongly indicates just the reverse, i.e., it shows a diminution of phospholipids in cataractous lenses as the cataract approaches maturity.

As already stated, most of the previous work on the linids of crystalline lenses, especially cataractous lenses, has been of aualitative nature only and no distinction has been made between those removed by the intra- and extra-capsular methods. The significance of such a distinction has been pointed out by Zehender, Matthiessen, and Jacobsen $(1877,1879)$ with respect to cholesterol, the latter being present in much larger quantities in the nucleus. By analogy one would expect this to be true of phospholipids or 
lipids in general. Furthermore, no attempt has been made to compare the phospholipid content of incipient cataracts with that of more advanced types, also the age factor has been frequently neglected. In the present study all these points have been carefully considered and for this reason the results differ diametrically from those of previous investigations.

The fact that many investigators found, by means of a polariscope, myelin-like, birefractive substances in cataractous, but not in normal lenses, does not indicate an increase of phospholipids in toto in cataractous lenses as compared with normal lenses; these myelin-like, birefractive substances, as Krause $(1934,1935)$ points out, arise in all probability from the unmasking (1) of the phospholipids, i.e., lecithin, kephalin, and sphingomyelin, and (2) of the cerebrosides, namely, kerasin, phrenosin, nervone, and hydroxynervone. In addition, many organic and inorganic substances, such as calcium salts and cholesterol esters may also be birefractive. Under the influence of certain agents, such as infra-red rays, ultra-violet rays, electric shock, diabetic ketosis, faulty metabolism, blunt injury to the eye, etc., evidently some sort of disruption occurs in the phospholipid molecule and the fragments separate out in the form of liquid spherocrystals or oil droplets which may consist of glycerol and fatty acids. In their natural state the lipids act as protective agents for the tissue protein against excessive water absorption and the influence of certain toxic substances. When, however, the lipids decompose, they not only lose this protective function, but, in addition, liberate harmful substances such as fatty acids, which may tend to coagulate the lens protein (see bibliography by O'Brien and Salit, 1931) or combine with calcium, forming more or less insoluble calcium soaps. The decomposition of the phospholipids may even proceed to the point of liberation of the phosphorus from its choline radical. This phosphorus then goes into the formation of the insoluble calcium phosphate, which is not extractable from the lens by the usual fat solvents. The end-result, as ascertained by the colorimetric method," is diminution in phospholipids in cataractous lenses. This is in accordance with Wessely (1922) who detected birefractive calcium soaps, phosphates, and carbonates mixed with cholesterol in cataractous lenses. This explanation is also strongly supported by the fact that the calcium content of cataractous lenses increases proportionately with the development of the cataract (Salit, 1933), most of the calcium evidently being derived from the surrounding aqueous and

\footnotetext{
* It is the phosphorus content of phospholipids that is estimated in the colorimetric method, and from the phosphorus the amount of phospholipid is calculated in terms of lecithin.
} 
vitreous humours. Some of the decomposition products may also disappear from the lens by diffusion into the surrounding aqueous and vitreous humours.

\section{Experimental Technique}

The chief differences in the phospholipid values of crystalline lenses, as reported by a number of investigators, are to be attributed to differences in methods, some of which are less reliable than others. For this reason it is of prime importance to include a short description of the modified Whitehorn's (1924) colorimetric method which was employed.

All lenses were studied with the slit-lamp microscope and extracted by the intra-capsular method. The lens was then placed on a small piece of filter paper of known weight (ca. $0.1 \mathrm{gm}$.) and weighed on a sensitive balance. It was spread into a thin layer on the filter paper by means of a porcelain spatula and the paper was rolled in such a way that the lens paste came to lie between the two surfaces. The preparation was placed in a drying oven for approximately one hour at a temperature of $60^{\circ} \mathrm{C}$. in order to drive off excessive moisture without permitting it to become entirely dry. The latter precaution was taken to prevent possible occlusion of lipids in subsequent extractions with fat solvents. The specimen was placed in a 25 c.c. Erlenmeyer flask and covered with 2 c.c. of chloroform. It was allowed to stand in the dark, at room temperature, for one day or longer, after which the mass was macerated with a blunt stirring rod and the extract decanted on a small filter and filtered into specially made pyrex test-tubes, $6 \times \frac{3}{4}$ inches, graduated into 15,20 , and 25 c.c. The pulverized residue in the flask was then treated with 2 c.c. of $1: 4$ ether-alcohol mixture and the extract filtered into the same test-tube. This was repeated twice with acetone, after which the filter paper was washed three times with 0.5 c.c. portions of acetone. The combined extracts were evaporated at $65^{\circ} \mathrm{C}$. To the lipid residue in the test-tube were added 2 c.c. of $1: 1$ mixture of sulphuric and perchloric acids. The test-tubes were covered with vials of an appropriate size and imbedded in a sandbath. The sandbath was heated with a Bunsen burner having a burner tip with six horizontal holes, and the flame was so adjusted that complete digestion occurred in three hours. Care was taken to stop digestion as soon as the contents became perfectly clear. If digestion is continued much longer there may be some loss in the phosphorus content. After cooling, the contents were diluted with distilled water to 15 c.c. and then thoroughly mixed with a stirring rod. For standard, a similar tube, containing $0.05 \mathrm{mg}$. phosphorus in a 5 c.c. volume of solution, plus 2 c.c. of the sulphuric-perchloric acid reagent, 
was diluted in the same way. At this point the following reagents were added to both the sample and the standard, as outlined by Whitehorn: 2 c.c. of a twenty per cent. sodium sulphite solution, 2 c.c. of the molybdate reagent, and 1 c.c. of a one per cent. hydroquinone solution.* The contents were mixed with a stirring rod after each addition. The tubes were immersed in boiling water for 15 minutes, then cooled in ice water, after which the colours were compared in the usual manner. The calculation was carried out as follows :-

$\frac{\mathrm{St} \times 1.253 \times 100}{\mathrm{~S} \times \text { wt. of lens in } \mathrm{gm} .}=$ milligrams phospholipid, where $\mathrm{St}=$ the reading of the standard; $\mathrm{S}=$ the reading of the sample; $1.253=$ milligrams phospholipid corresponding to $0.05 \mathrm{mg}$. of phosphorus in the standard; $100=$ per cent. or $100 \mathrm{gm}$. of the lens substance.

This procedure estimates phospholipid in terms of lecithin. Of all the phospholipids, lecithin is the most abundant in animal tissue, including the crystalline lens. According to Krause, there is almost twice as much lecithin in one year-old bovine lenses as there are kephalins and sphingomyelins combined. It is also assumed that the other phospholipids do not differ greatly from lecithin with respect to their relative phosphorus content. The phospholipids, therefore, may be expressed in terms of lecithin without committing gross errors in the calculation of their absolute amounts. But even if this study entailed such errors with respect to their absolute amounts, they in no way would invalidate its main object, namelv, the answer to the ruestion: Does the phospholipid content of cataractous lenses differ in any way from that of normal lenses?

\section{Results}

In Table I the results are summarized in terms of minimum, maximum, and average phospholipid values as found in the three groups of cataractous lenses, i.e., incipient, intumescent, and mature types. In Table II the results, also in terms of minimum, maximum, and average values, are arranged according to age in decades.

From these data it is seen that the phospholipid content of incipient cataracts $(0.534$ per cent.) exceeds that of intumescent cataracts $(0.481$ per cent.) by $53 \mathrm{mg}$. per cent., and that of mature cataracts (0.470 per cent.) by $64 \mathrm{mg}$. per cent. A similar relation-

* For best results one should use a perfectly colourless bydroquinone solution. It is possible to preserve it in this condition for about one week by keeping it in the ice box in the dark and without the addition of sulphuric acid. The molybdate reagent, likewise, should be kept in the ice box. 


\section{Phospholipid Content of Cataractous Human Lenses 669}

ship is expressed also by the corresponding absolute phospholipid values, these being $1.075,0.971$, and $0.932 \mathrm{mg}$. for incipient, intumescent, and mature types respectively. The same tendency is displayed also by their limits in variation, both on the basis of per cent. and absolute amount of phospholipid. This is more apparent if only the incipient and the mature stages are compared, leaving out the intermediate or intumescent stage. This stage is not as clearly defined in its clinical characteristics as the other two, and besides, it is represented by a much smaller number of lenses as compared with the incipient and mature stages. For this reason, the results for this type of lenses are subject to greater irregularities.

TABLE I-Minimum, Maximum, and Average Phospholipid Values of Cataractous Lenses in Various Stages of Development.*

\begin{tabular}{|c|c|c|c|c|c|}
\hline Stage & $\begin{array}{l}\text { Age of } \\
\text { Patient }\end{array}$ & $\begin{array}{c}\text { Duration, } \\
\text { years }\end{array}$ & $\begin{array}{c}\text { Weight, } \\
\text { gm. }\end{array}$ & $\begin{array}{l}\text { Mg. phospho- } \\
\text { lipid, per lens }\end{array}$ & $\begin{array}{l}\text { Per cent. } \\
\text { phospholipid }\end{array}$ \\
\hline Incipient & $42-87$ & $0 \cdot 7-7 \cdot 0$ & $0.1392-0.2970$ & $0.691-1.675$ & $0.402-0.702$ \\
\hline Averages - & $67 \cdot 2(70)$ & $2 \cdot 7(68)$ & $0.2045(69)$ & $1.075(62)$ & $0.534(60)$ \\
\hline Intumescent - & $70-85$ & $1 \cdot 0-12 \cdot 0$ & $0.1622-0.2408$ & $0 \cdot 722-1 \cdot 253$ & $0.368-0.597$ \\
\hline Averages - & $74^{\circ} 0(12)$ & $3 \cdot 3(12)$ & $0.2055(12)$ & $0.971(11)$ & $0.481(11)$ \\
\hline Mature - & $52-81$ & $1^{\circ} 0-25^{\circ} 0$ & $0.1127-0.2957$ & $0.511-1.362$ & $0.241-0.791$ \\
\hline Averages - & $69 \cdot 4$ (34) & $4.4(35)$ & $0.1990(36)$ & $0.932(28)$ & $0.470(28)$ \\
\hline
\end{tabular}

TABLE II-Minimum, Maximum, and Average Phospholipid Values of Cataractous Lenses according to Age in Decades.

\begin{tabular}{|c|c|c|c|c|c|c|}
\hline Decade & & $\begin{array}{l}\text { Age of } \\
\text { Patient }\end{array}$ & $\begin{array}{c}\text { Duration, } \\
\text { years }\end{array}$ & $\begin{array}{l}\text { Weight, } \\
\text { gm. }\end{array}$ & $\begin{array}{l}\text { Mg. phospho- } \\
\text { lipid, per lens }\end{array}$ & $\begin{array}{c}\text { Per cent. } \\
\text { phospholipod }\end{array}$ \\
\hline v & - & $42-49$ & $1 \cdot 0-50$ & $0.1392-0.2731$ & $0.511-1.266$ & $0.277-0.606$ \\
\hline Averages & - & $45 \cdot 1(7)$ & $2 \cdot 8(6)$ & $0.2062(7)$ & $0.904(6)$ & $0.453(6)$ \\
\hline VI & - & $51-59$ & $0 \cdot 8-7 \cdot 0$ & $0.1553-0.2358$ & $0 \cdot 570-1 \cdot 271$ & $0.317-0.702$ \\
\hline Averages & - & $55 \cdot 1(14)$ & $2 \cdot 4(13)$ & $0.1871(14)$ & $0.904(13)$ & $0.506(13)$ \\
\hline VII & - & $61-70$ & $0 \cdot 7-7 \cdot 0$ & $0.1500-0.2628$ & $0.548-1.362$ & $0.241-0.791$ \\
\hline Averages & - & $66 \cdot 3(41)$ & $3.0(40)$ & $0.1942(40)$ & $0.977(35)$ & $0.513(34)$ \\
\hline VIII - & - & $71-80$ & $10-25^{\circ} 0$ & $0.1591-0.2970$ & $0 \cdot 704-1.663$ & $0.371-0.660$ \\
\hline Averages & - & $75 \cdot 6(46)$ & $4 \cdot 1(44)$ & $0: 2120(46)$ & $1.056(38)$ & $0.513(38)$ \\
\hline IX & - & $81-87$ & $1 \cdot 0-5 \cdot 0$ & $0.2040-0.2957$ & $1.076-1.675$ & $0.441-0.713$ \\
\hline A verages & - & $83 \cdot 8(8)$ & $2 \cdot 8(8)$ & $0.2401(7)$ & $1 \cdot 254(8)$ & $0.533(7)$ \\
\hline
\end{tabular}

* Figures in parentheses indicate the number of lenses examined. 
In agreement with data reported previously (Salit, 1933 ; Salit and O'Brien, 1935), it is seen from Table I that, on the average, cataractous lenses of the mature type weigh slightly less $(0.1990 \mathrm{gm}$.) than those of the incipient type $(0.2045 \mathrm{gm}$. $)$. The average durations of the cataractous conditions, also in accordance with previous data, are $2.7,3.3$, and 4.4 years for the incipient, intumescent, and mature stages respectively.

From the data in Table II, where the arrangement is according to age, all the values (minima, maxima, and averages) in the last two columns (marked "Mg. phospholipids per lens" and "\% phospholipids") increase with age. This is true also with respect to the relative average weights of the lenses, and to a lesser degree with respect to their minima and maxima.

\section{Summary}

The phospholipid content of each of 100 cataractous human lenses was estimated. All the lenses were examined with the slitlamp microscope and classified as incipient, intumescent, or mature cataracts, after which they were removed in toto by the intracapsular method. The lenses were weighed immediately after removal and the lipids were extracted successively with chloroform, ether-alcohol, and acetone. The phospholipids were estimated as lecithin by a modification of the colorimetric method of Whitehorn. In this study are included: age of the patient, stage and approximate duration of the cataract, weight of the lens, milligrams of phospholipid per lens, and per cent. of phospholipid.

The results indicate a definite decrease in phospholipids of cataractous lenses as they approach maturity. This fact is shown by both the absolute and relative values, the former decreasing from $1.075 \mathrm{mg}$. per lens in incipient cataracts to $0.971 \mathrm{mg}$. in intumescent, and $0.932 \mathrm{mg}$. in mature cataracts, and the relative values decreasing from 0.534 per cent. in incipient to 0.481 per cent. in intumescent, and 0.470 per cent. in mature cataracts. The phospholipids, however, increase with age, both on the absolute and relative basis. This is shown by the data as arranged according to age in decades, covering all ages from 42 to 87 years inclusively ; thus the absolute value of $0.904 \mathrm{mg}$. per lens or 0.453 per cent. in the fifth decade is increased to $1254 \mathrm{mg}$. per lens or 0.533 per cent. in the ninth decade.

So far it has been assumed that the phospholipid content of cataractous lenses increases as the cataract advances. This error was due chiefly to the following: (1) Omission of age ; (2) failure to differentiate between intra- and extra-capsular lenses; (3) failure to classify the lenses according to the maturity of the cataract; and (4) confusion of phospholipids in their natural forms with 
their decomposition products, e.g., birefractive myelins, liquid spherocrystals, calcium soaps, and other birefractive substances.

Dr. C. S. O'Brien, Head of the Department of Ophthalmology, gave valuable help throughout this work.

\section{BIBLIOGRAPHY}

Busacca, A. (1925).-Résultant particulier de l'examen histologique d'un cas de cataracte noire. Rev. gen. d'Ophtal., Vol. XXXIX, pp. 439-445.

Cahn, A (1881).-Zur physiologischen und pathologischen Chemie des Auges. Zeitschr. f. physiol. Chemie, Vol. V, pp. 213-232

Goldschmidt, M. (1922).-Die Lipoide der Linse. Biochem. Zeitschr., Vol. CXXVII, pp. 210-213.

Hoffmann, M. (1913.-Ueber doppelbrechende Myeline in Katarakten. Münch. Med. Wochenschr., Vol. LX (I), p. 741. (1914).-Der kataraktöse Zerfallsprozess der Linse und seine Darstellung im Reagenzglase. Münch. Med. Wochenschr., Vol. LXI (I), pp. 584-586.

Jess, A. (1913). - Beiträge zur Kenntnis der Chemie der normalen und der pathologisch veränderten Linse des Auges. Zeitschr. f. Biologie, Vol. LVI, pp. 93-142.

Kranz, H. W. (1927).-Die polarisationsmikroskopische Untersuchung der kataraktös getrübten Linse. Arch. f. Ophthal., Vol. CXVIII, pp. 571-605.

Krause, A. C. (1932).- The Chemistry of the Lens. Yale Jl. of Biol. and Med., Vol. V.

- (1934).- The Biochemistry of the Eye. The Johns Hopkins Press, Baltimore, U.S.A.

- (1935).-Chemistry of the Lens. VI. Lipids. Arch. of Ophthal., Vol. XIII, pp. 187-190.

Laptschinsky, M. (1876).-Ein Beitrag zur Chemie des Linsengewebes. Arch. $f$. d. ges. Physiol., Vol. XIII, pp. 631-634.

Leinfelder, P. J., and Salit, P. W. (1934).-The Lipids of Retina, Brain, and Blood. Amer. Jl. Ophthal., Vol. XVII, pp: 619-624.

Mettenheimer. (1857, 1858).-Cor.-Bl. d. Ver. f. gemeinsch. Arb. z. Ford. d. wissensch. Heilk., No. 24, p. 331 ; No. 31, p. 467. Cited by Kranz (1927).

Metzger. (1931). - Lipoidbefunde bei Cataracta coronaria. Klin. Monatsbl. $f$. Augenheilk., Vol. LXXXVII, p. 850.

O'Brien, C. S., and Salit, P. W. (1931),-Iso-Electric Point of Lens Protein. Arch. of Ophthal., Vol. VI, pp. 870-876.

Salit, P. W. (1930).-Calcium Determinations on Cataractous Human Lenses. Amer. Jl. Ophthal., Vol. XIII, pp. 1072-1075.

(1931).-Chemical Studies of Lipids of Normal Animal Lenses, Cataractous Human Lenses and the Blood of Patients with Cataract. Arch. of Ophthal., Vol. V, pp. 354-361.

(1933).-Calcium Content and Weight of Human Cataractous Lenses. Arch. of Ophthal., Vol. IX, pp. 571-578.

Salit, P. W., and O'Brien, C. S. (1935).-Cholesterol Content of Cataractous Human Lenses. Arch. of Ophthal., Vol. XIII, pp. 227-237.

Toufesco, S. (1906).- Sur le cristallin pathologique. Ann. d'ocul., Vol. CXXXVI, pp. 1-16.

Vogt, A. (1922).-Weitere Ergebnisse der Spaltlampenmikroskopie des vorderen Bulbusabschnittes. IV. Präsenile und senile Linsentrübungen. Arch. $f$. Ophthal., Vol. CVIII, pp. 192-218.

Wessely, K. (1922).-Zwei Kleine Beiträge zur Pathologie der Linse. Arch. f. Augenheilk., Vol. XCI, pp. 158-166.

Whitehorn, J. C. (1924).-A Method for the Determination of Lipoid Phosphorus in Blood and Plasma. Jl. Biol. Chem., Vol. LXII, pp. 133-138.

Zehender, W., Matthiessen, L., and Jacobsen, $O$. (1877, 1879).- Ueber die Brechungscoefficient und die chemische Beschaffenheit kataraktöser Linsensubstanz. Klin. Monatsbl. f. Augenheilk., Vol. XV, pp. 311-319: Vol. XVII pp. 307-317. 